Artigos

\title{
TOYS AS TEXTS: TOWARDS A MULTIMODAL FRAMEWORK TO TOYS' SEMIOTICS
}

\author{
BRINQUEDOS COMO TEXTOS: POR UMA ABORDAGEM \\ MULTIMODAL PARA SEMIÓTICA DOS BRINQUEDOS
}

\section{Danielle Barbosa Lins de Almeida*}

\begin{abstract}
Toys, in their myriad versions, have been historically considered as objects of investigation insofar as their educational use, play and effects are concerned. Nevertheless, it must be said that academic research in the direction of toys' multimodal configurations and meaningmaking potential has been quite scant, despite a few relevant studies in the area (CALDASCOULTHARD \& VAN LEEUWEN, 2001, 2002, 2004; MACHIN \& VAN LEEUWEN, 2009; ALMEIDA, 2006; 2008; 2009; 2014; 2017; 2018). This paper presentation attempts at demonstrating how systems of signification derived from the Grammar of Visual Design (VG) by Kress and van Leeuwen (2006 [1996]), such as the subsystem of modality (reality value), when combined with other concepts, such as Varney's (1999; 2003) concept of technocracy of sensuality and Fleming's (1996) notions of harder representationality and tactile attachment, have proved effective as theoretical tools to toy semiotics by allowing to go beyond the investigation of toys' two-dimensional perspective to check on their material configurations such as texture, smell, kinetic possibilities and the degree of realism of these three-dimensional childhood representations. By means of primarily linguistic lens, I believe to contribute to social semiotic research through the articulation of the analysis of linguistic aspects of data with the discussion of social issues such as gender roles, diversity, representation and inclusion. All in all, my main intention is to propose an innovative, exploratory look into toys as texts as well as ideologically-loaded cultural artefacts.
\end{abstract}

Keywords: toys; semiotics; multimodality.

\section{RESUMO}

Os brinquedos, em sua miríade de versões, historicamente foram considerados objetos de investigação no que diz respeito ao seu uso e efeitos pedagógicos durante a brincadeira. No entanto, deve-se dizer que a pesquisa acadêmica na direção das configurações multimodais e dos potenciais de significado dos brinquedos é bastante escassa, apesar de alguns estudos relevantes na área (CALDAS-COULTHARD \& VAN LEEUWEN, 2001, 2002, 2004; MACHIN \& VAN LEEUWEN, 2009; ALMEIDA, 2006; 2008; 2009; 2014; 2017; 2018).) Metodologicamente, tentarei demonstrar como os sistemas de significação derivados da Gramática do Design Visual (GV), de Kress e van Leeuwen (2006), como o subsistema de modalidade (valor da realidade), quando combinados com outros conceitos, como a noção de tecnocracia da sensualidade de Varney (1999) e os conceitos de representacionalidade densa e apego tátil de Fleming (1996) se mostraram eficazes como instrumento teórico para

\footnotetext{
* Universidade Federal da Paraíba, UFPB, Paraíba, PB, Brasil. danielle.almeida@gmail.com.

Bolsista de Produtividade em Pesquisa PQ2 - CNPq.

Orcid: https://orcid.org/0000-0003-1472-6083
} 
a semiótica dos brinquedos, permitindo ir além da investigação da perspectiva bidimensional de suas propagandas, a fim de verificar configurações materiais como a textura, o cheiro, as possibilidades cinéticas e o grau de realismo dessas representações tridimensionais da infância. Por meio de lentes essencialmente linguísticas, acredito contribuir para a pesquisa em semiótica social através da articulação da análise dos aspectos linguísticos dos dados com a discussão de questões sociais mais amplas, tais como papéis de gênero, diversidade, representação e inclusão. Em suma, minha principal intenção é propor um olhar inovador e exploratório sobre os brinquedos, tanto como textos quanto como artefatos culturais carregados de ideologias.

Palavras-chave: brinquedos; semiótica; multimodalidade.

\section{INTRODUCTION}

Throughout the last decades, a lot has been said about toys as texts: that they are a meeting place for various discourses (FALKSTROM, 2003); that intimately relate to what goes on in society (CALDAS COULTHARD AND VAN LEEUWEN, 2002); that more than objects, they are occurrences (FLEMING, 1996).

Indeed, toys have finally left the shelves in toy stores to be considered as texts, as multimodal objects to be manipulated, read and interpreted in their full meaning-making potential, besides their playing affordances. Caldas Coulthard \& van Leeuwen $(2001,2002,2004)$ have referred to toys as being interdiscursive, as holding intertextual links with mass media and also as being dialogical (2002, my italics, p. 96). That being so, toys can be regarded as a communicative semiotic system, able to produce representational, interactive and compositional meanings (KRESS AND VAN LEEUWEN, 2006) just as any other language system.

As texts, part of a language system, toys first and foremost appeal to our affective reactions, and that has to do with their interpersonal meanings, which most times is associated to toys' material qualities. Whether they are made of metal, plastic, wood or soft materials, they reveal cultural references and produce affective reactions.

Be that as it may, the apparently innocuous relationship that is established between the toy and the child during the playing activity is, in fact, ideologically loaded, as toys should be taken as any other type of text which overtly expresses its position.

This article therefore aims at demonstrating toys' meaning-making potential as texts by describing some of the projects which have been conducted both in England and in Brazil since late 1990s about the verbal and visual language of toys. It also presents an innovative framework aimed at the analysis of toys' material qualities, based on and linked to Kress \& van Leeuwen's (2006) systems for modality within their interactive visual metafunction. 
In the next section, the project Toys as Communication, aimed at the social semiotic study of toys as texts, conducted by Theo van Leeuwen and Carmen Rosa Caldas-Coulthard in the late 1990's will be described.

\section{TOYS AS COMMUNICATION}

The project Toys as Communication was developed in Britain from 1998 to 2000 with two main objectives: (1) to investigate toys as semiotic objects and their messages about the social world, (2) to read toys as texts loaded with their implicit and explicit agendas (my italics) ${ }^{1}$.

For two and half years, van Leeuwen \& Caldas-Coulthard investigated toys' semiotic aspects such as their material qualities, considering toys' physical and cultural attributes, skin colour as well as their degree of stereotyping and individuality. In their study, van Leeuwen \& Caldas-Coulthard applied a descriptive framework to different toy representations such as Playmobil, Barbie dolls, Action Men, Teddy Bears and Toys for Babies such as pram rattles by focusing on aspects such as toys' kinetic design, the marketed language in their catalogues, advertisements and packages and the analyses of children and adults' narratives while reporting the memories of playing with their most cherished toys such as teddy bears. Table 1 summarises their approach and methodological procedures towards toys' investigation.

\section{Table 1. Descriptive framework of the project Toys as Communication}

[Source:author]

\begin{tabular}{|c|c|c|}
\hline TOPIC & DESCRIPTIVE FRAMEWORK & RESEARCH ACTIVITIES \\
\hline $\begin{array}{l}\text { PLAYMOBIL AND SIMILAR } \\
\text { MINIATURE FIGURES }\end{array}$ & $\begin{array}{l}\text { - kinetic design, degree of } \\
\text { stereotyping/individuality and } \\
\text { attributes } \\
\text { - (skin colour/hair style/dress) }\end{array}$ & $\begin{array}{l}\text { - Recording \& transcription of } 3 \text { hours } \\
\text { [nursery school setting + home setting] } \\
\text { - Identification of preferred meanings } \\
\text { - Creation of inventory of Playmobil } \\
\text { ranges }\end{array}$ \\
\hline BARBIE DOLLS AND ACTION MEN & $\begin{array}{l}\text { - connection between material objects. } \\
\text { images and textuality }\end{array}$ & $\begin{array}{l}\text { - Examination of kinetic design, toy } \\
\text { boxes and advertising material } \\
\text { [catalogues and Internet] }\end{array}$ \\
\hline $\begin{array}{l}\text { TOYS REPRESENTING HUMAN } \\
\text { BEINGS AND ANIMALS } \\
\text { [TEDDY BEARS] }\end{array}$ & $\begin{array}{l}\text { role of teddy bears in indlvidual lives } \\
\text { and the ways they point to discourses } \\
\text { of the self; the role of teddy bears in } \\
\text { public settings and publishing world }\end{array}$ & $\begin{array}{l}\text { - Questionnaire survey [ } 300 \text { qs, } 98 \\
\text { replies] } \\
\text { - } 40 \text { narratives of primary school } \\
\text { children about teddies }+40 \text { school } \\
\text { projects [take home for a day] } \\
\text { - Narrative analyses of } 20 \text { children's } \\
\text { books featuring teddy bears }\end{array}$ \\
\hline TOYS FOR BABIES & $\begin{array}{l}\text { Material qualities + kinetic possibilities } \\
\text { of pram rattles and the like [+ verbal- } \\
\text { visual texts on packaging, ads, } \\
\text { parenting magazines \& books] }\end{array}$ & $\begin{array}{l}\text { Analysis of the toys + discourses of } \\
\text { parenting and childhood [ads, } \\
\text { catalogues, texts from developmental } \\
\text { psychology, qs to parents] }\end{array}$ \\
\hline \multicolumn{3}{|c|}{$\begin{array}{l}\text { Kinetic design (hold objects? Parts can be taken off/exchangedi) } \\
\text { The ways in which the identity of the figures is signified (physical/ cultural attributes/skin colour) } \\
\text { Degree of stereotyping/individuality }\end{array}$} \\
\hline
\end{tabular}

1. Final Report on part of the Toys as Communication Project - the Social Semiotics of Toys, as shared by one of the researchers. 
In one of the articles derived from the Toys as Communication project - entitled Stunning, Shimmering, Iridescent: Toys as Representation of Gendered Social Actors - van Leeuwen \& Caldas-Coulthard addressed questions regarding the gender and social values attached to toys' representations, which included:

- What are the current kinds of dolls?

- Which ages, ethnicities, professions are available as toys and which are not?

- What are the changeable or unchangeable features in toys?

- How has gender identity changed across time in toys' representations?

- How does gender get represented in toys?

- How are boys and girls, men and women represented? Old ones? Young ones? Male? Female? Black? White?

- What are the potential social meanings which differentiate girls' from boys' toys?

- What are the values attached to toys' representations?

- Who gets included and excluded in the toy world?

Flash forward to 2010s, issues such as representation and diversity seem to appear as tendencies in toy campaigns in this decade, as I have had the chance to verify through my own projects, named Toys on Focus and Multimodality and Cbildbood, to be detailed in the section that follows.

\section{TOYS ON FOCUS \& MULTIMODALITY AND CHILDHOOD}

Similar to the Toys as Communication project, both the Toys on Focus (20152018) and the Multimodality \& Childbood (2018-2021) project, developed through the Ministry of Science, Technology, Innovations and Communications (CNPq) in Brazil have been focusing on the investigation of childhood representations in different discursive domains. Using the Grammar of Visual Design (GVD) by Kress \& van Leeuwen (2006) and other approaches such as Halliday's Systemic Functional Grammar (1994) as the main theoretical tools, analyses have been conducted on the visual and the verbal configurations of childhood representations such dolls both in their two and three-dimensional configurations - on the marketed language of toys' packages, websites and social media campaigns, as a way to investigate how issues such as gender roles, diversity, representation and inclusion reverberate in toys' representations (Figure 2). 
Table 2: Descriptive framework of the projects Toys on Focus and Multimodality \& Childhood [Source:author]

\begin{tabular}{|c|c|c|}
\hline TOPIC & DESCRIPTIVE FRAMEWORK & RESEARCH ACTIVITIES \\
\hline FASHION DOLLS & $\begin{array}{l}\text { - Verbaland visual analysis of web } \\
\text { advertisements [two-dimensional texts] of } \\
\text { Brazilan fashion dioll Susi and North- } \\
\text { American dols The Eratz [GVD+SFG] }\end{array}$ & $\begin{array}{l}\text { Description + analysis of visual syntactic } \\
\text { patterns [at representational, interactive } \\
\text { and compositional level] and verbal } \\
\text { features [lexico-grammatical patterns] of } \\
\text { foshion dols' 'ods } \\
\text { Visit to toy museums and childcare centers } \\
\text { [in Brazil and Australia] }\end{array}$ \\
\hline $\begin{array}{l}\text { DIVERSITY, } \\
\text { REPRESENTATION \& } \\
\text { INCLUSION IN TOYS }\end{array}$ & $\begin{array}{l}\text { - Identification of verbal and visual features } \\
\text { of contemporary toy campaigns focusing } \\
\text { on diversity, representation and inclusion } \\
\text { [American Gif TM, Toy Like Me } \mathrm{e}^{\mathrm{TM}} \text {, } \\
\text { Lammily } \mathrm{TM}+\mathrm{My} \text { Family Bulders } \\
\text { photographs of toys and ther } \\
\text { packages, websites, social media } \\
\text { campaigns }\end{array}$ & $\begin{array}{l}\text { - Identification of visual and verbal aspects of } \\
\text { toy campaigns via systems of signification } \\
\text { [representational interactive }+ \\
\text { compositional level] + lexicogrammatical } \\
\text { features } \\
\text { - Observation of contemporary toys' kinetic } \\
\text { properties through photographs and } \\
\text { campaigns }\end{array}$ \\
\hline BABY DOLLS & $\begin{array}{l}\text { - Description of multimodal properties of } \\
\text { Brazilian baby dolls' packages [aural, } \\
\text { olfactory, tactile + verbal and visual } \\
\text { aspects] }\end{array}$ & $\begin{array}{l}\text { - Visit to toy stores and museums [in Brazil, } \\
\text { Portugal + USA] } \\
\text { - Analysis of textual and contextual meanings } \\
\text { - Identification of baby dolls' modality level }\end{array}$ \\
\hline \multicolumn{3}{|c|}{ 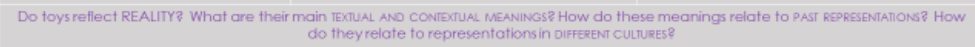 } \\
\hline
\end{tabular}

In terms of gender roles, by investigating the verbal and the visual texts of the web advertisements for best-selling Brazilian doll Susi and North-American dolls The Bratz in the early 2000s, I was able to relate these dolls representations to a rather stereotyped view of the female figure by means of predominantly conceptual structures (KRESS AND VAN LEEUWEN, 2006), although it has been possible to see the social changes experienced by women in recent years through the narrative visual structures (KRESS \& VAN LEEUWEN, 2006) of dolls like Susi occupying new career positions as a flight attendant or as a football player.

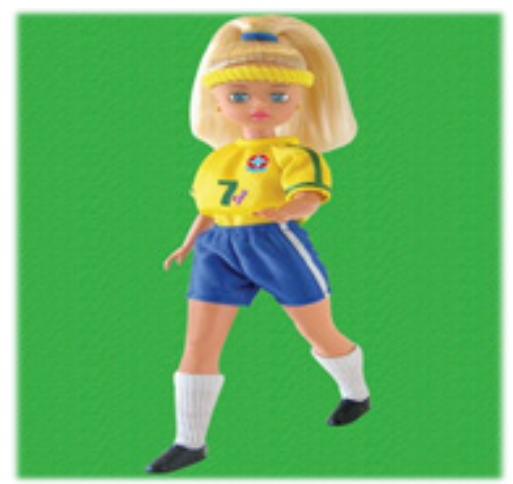

Figure 1. Susi Milene Domingues

Courtesy of Estrela@

Differently from Susi, the Bratz dolls were rarely seen within the context of the domestic or private sphere. The visuals and the verbals of the Bratz' advertisements 
promoted independence and assertiveness and ventured at new performances of being 'feminine', like "hitting the town" in order to celebratze independence or "hanging out with their girl counterparts", recurrent expressions in these dolls" advertisements.

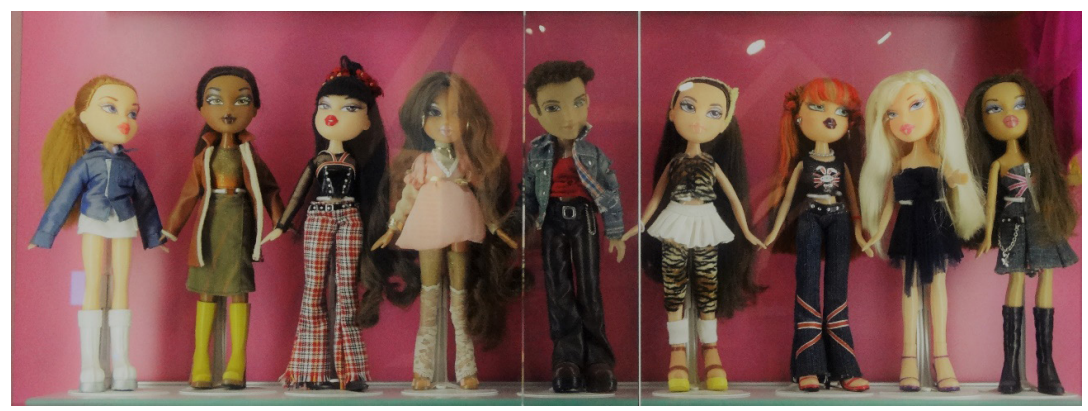

Figure 2. The Bratz dolls

Courtesy of The Strong Museum, Rochester, New York

In his review for the book Visual Communication - Handbook for Communication Sciences, Machin (2014) refers to my linguistic analysis of Brazilian doll Susi as rather detailed and based on social semiotic analysis to show that although there has been a move in Brazilian society towards the depiction of Brazilian women in professional careers through these dolls, this is usually done via lifestyles and consumer objects rather than through concrete activities (p.16).

In 2015 I had the chance to revisit Susi ten years after finishing my PhD research, through the Toys on Focus project and to my surprise, she was no longer in the toy shelves in Brazil. Susi doll had been out of the toy market since 2013 and toy manufacturer Estrela reported that in recent years Brazilian children's choices for toys have been then more targeted at toys such as Cake Factories (Faz de Verdade) and play dohs (Super Massas lines) ${ }^{2}$. This has probably been constructing a new kind of Brazilian childhood that does not rely so much on doll-playing as it did before.

In what concerns representation and diversity in toys, my studies have been pointing to a tendency towards a more realistic depiction in lines like Mattel's Barbie, who has been added more diversity into her material configurations. Similarly, toys like Lammily doll have been released in the toy market: she has proportions of an actual teenage woman with flexible material properties to open her legs, move her wrists, knees, elbows and feet (Figure 3).

2. Information collected through personal exchange by email. 

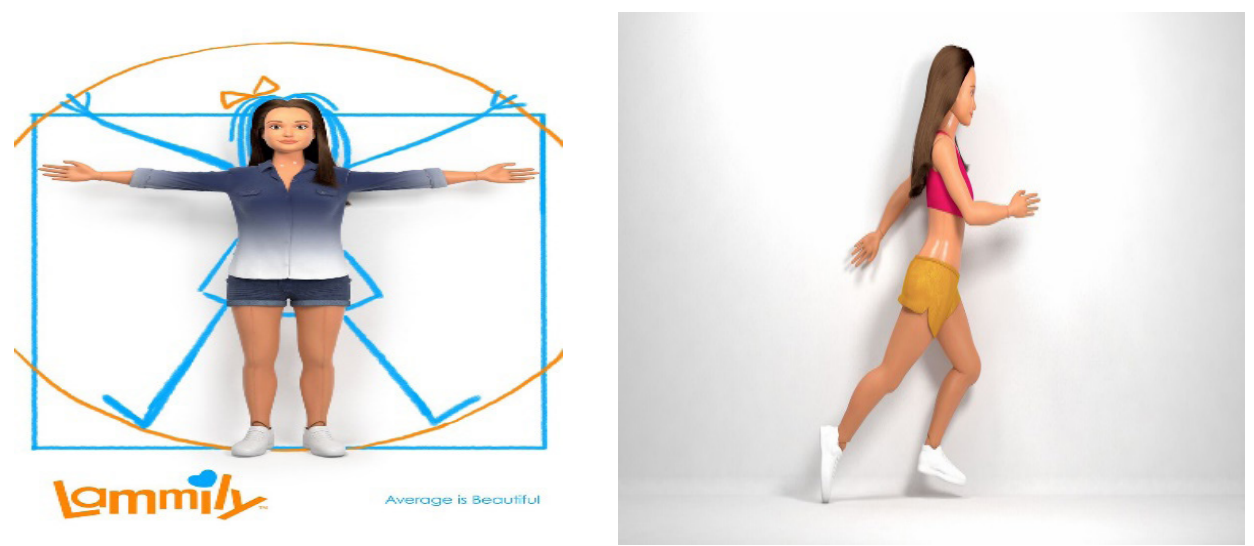

Figure 3. Lammily doll

Courtesy of Nickolay Lamm(C

Imperfect as anyone can be in real life, the Lammilly doll has scars, stretch marks, cellulite, acne and period patches which emulate the representation of a real teenager, which contrasts with Barbie's historical inability to move or stand on her own two feet, a discourse of play on her body that has been fiercely criticized by academics. In other words, the Barbie doll, though revolutionary in terms of historical meanings, has remained conservative at the level of her playing affordances.

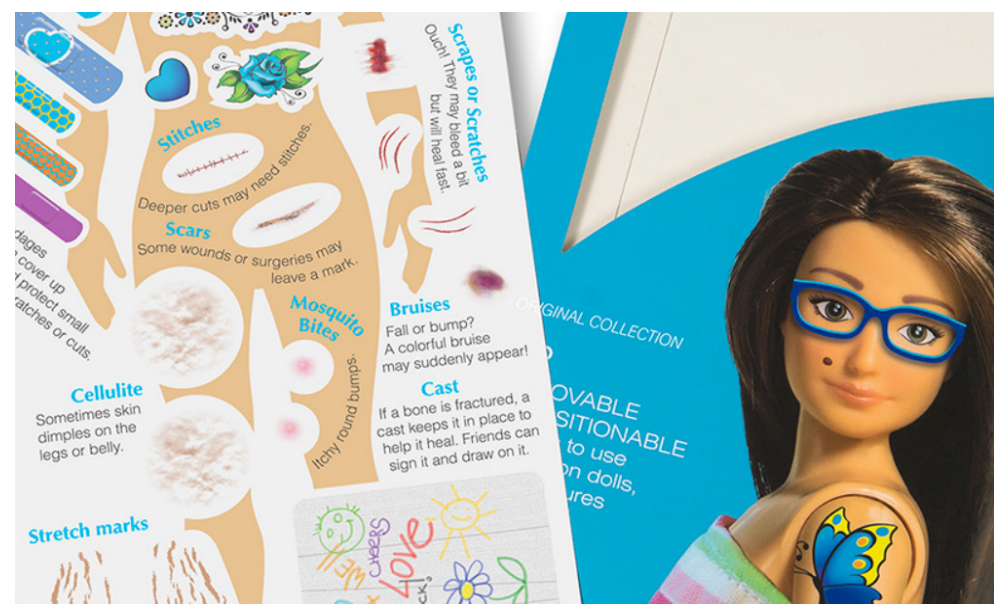

Figure 4. Lammily doll

Courtesy of Nickolay Lamm (C) 
Also with a view to promoting diversity, the American Girl Truly $M e^{\mathrm{TM}}$ line has put together forty American Girls in one of its latest campaigns, corroborating a sense of group identity, despite their differences. At the verbal level, that is fostered by a text that reinforces the celebration and acceptance of the differences. It says: "American Girl's mission is to celebrate girls. We embrace who they are today and look forward to who they will become tomorrow".

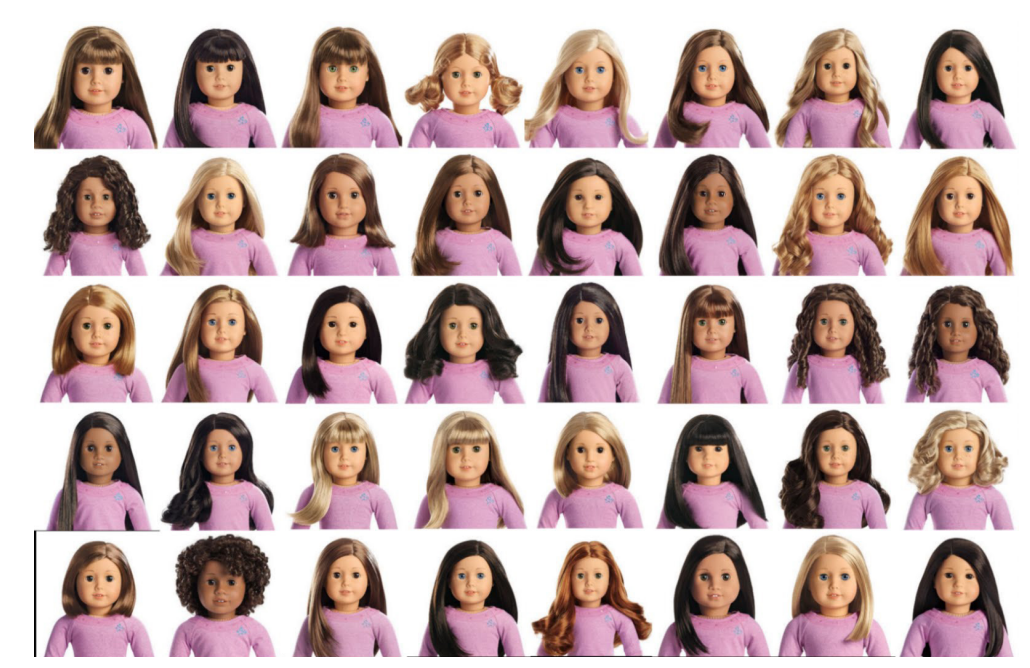

Figure 5. American Girl Truly $\mathrm{Me}^{\mathrm{TM}}$

Courtesy of American Girlo

The disruption of traditional narratives conceived in toy campaigns could also be attested in toy sets like MyFamilyBuilders $@$, a brand that takes pride in creating a world where parents and kids celebrate love and the values shared by all families, regardless of their colour, creed, sexual orientation and culture. This toy set allows children to build their characters and families as they wish, as it contains 48 wooden pieces and a board game with 25 cards that allow for over 2.000 matches per set. 


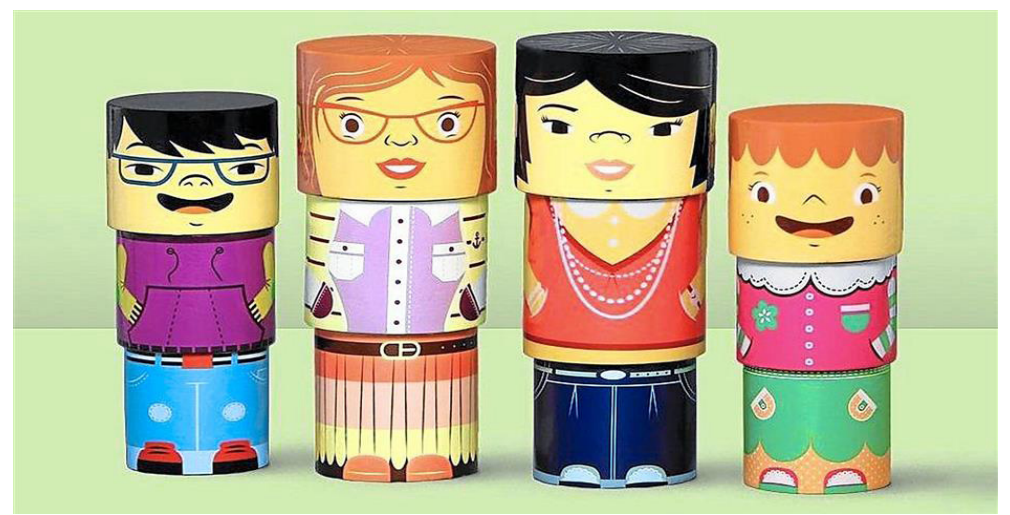

Figure 6. MyFamilyBuilders@

Courtesy of My Family Builders $($ )

Regarding inclusion in toys, campaigns such as \#ToyLikeMe, showcasing disability toys seem to reflect a more disability-inclusive society.

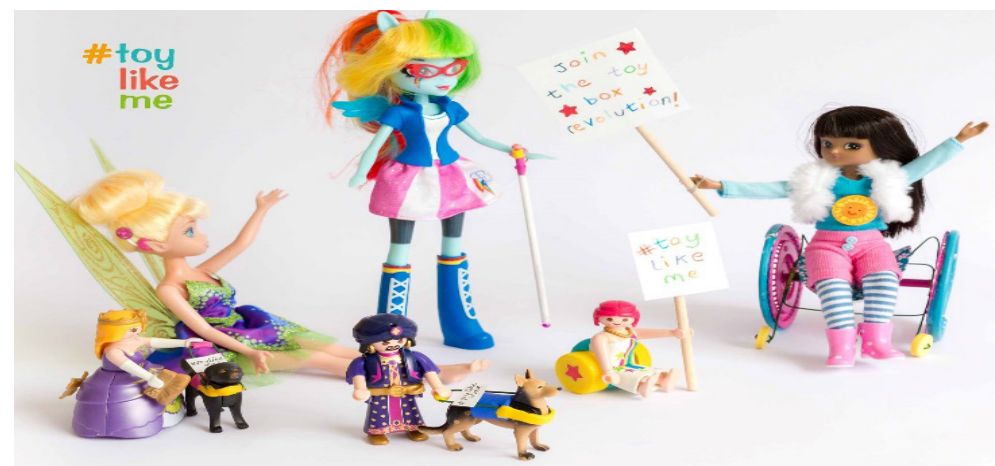

Figure 7. \#ToyLikeMe

Courtesy of ToyLikeMe@

Regarding the reality value in toys, baby dolls have called my attention for the increasing modality attached to their representations by the market. They have been considered the greatest phenomena of the toy market since 1900s, the period of the Industrial expansion (FLEMING, 1996).

My analyses on baby dolls and their packages within the Multimodality and Childhood project, have been assisted by some of the systems of signification of the Grammar of Visual Design, which has proved effective and applicable to the analysis of toys' material configurations. This will be clarified in the subsequent section. 


\section{BABY DOLLS' MULTIMODALITY}

My interest in the multimodal investigation of baby dolls and their packages derives from three main objectives: (1) identifying the multimodal properties of these artefacts; (2) discussing the roles provided by their texts and (3) reflecting about the kind of childhood that is gradually being constructed through these dolls' representations.

Two main questions have guided my incursion into the baby dolls' world: (1) Do baby dolls foster creativity in playing or through their pre-established props end up limiting children's imaginative potential? (2) How does baby dolls' realism enhance the fixing up of female children's identity as future mothers?

Looking back at the first drink-and-wet baby doll from the 1950s, named Dy-Dee (Figure 8), it is possible to see a set of pictures printed on the inside part of Dy-Dee's box, giving the little playing girl clues as visual instructions on how she should conduct her mothering roles while playing with the doll. Dy-Dee came with a manual on how the little child mother (a girl) should behave: "What every young mother should know", stated the manual.

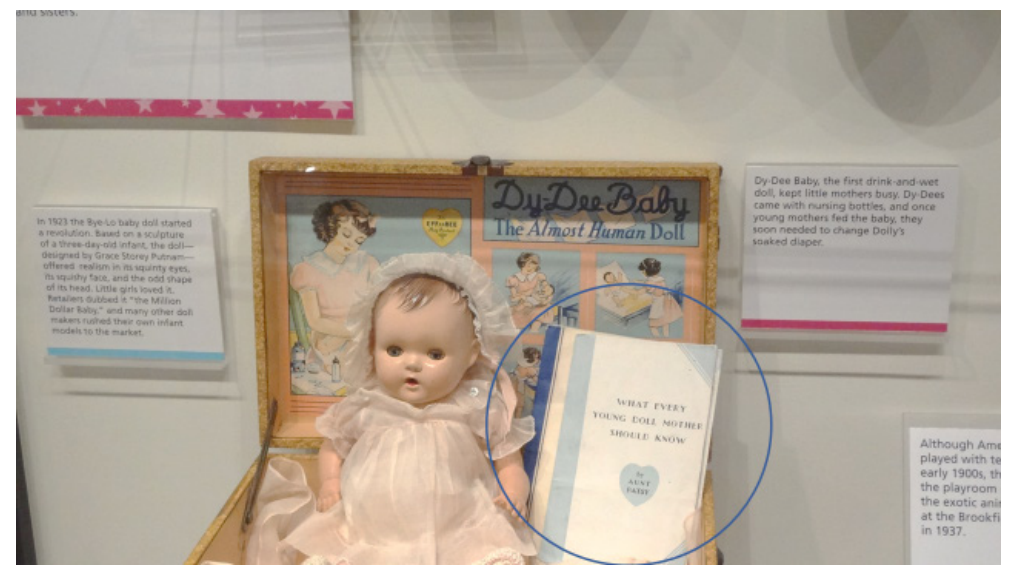

Figure 8. Dy-Dee Baby Doll

Courtesy of The Strong Museum, Rochester, New York

Flash forward to the baby dolls from 1970s, both Hush Li'l Baby and Li'l David baby doll (Figure 9) from 1977, included accessories in their packages such as a plastic pacifier, and a baby bottle. As for the latter, his package warned its potential buyer in orange letters about the high modality (KRESS \& VAN LEEUWEN, 2006) of Li'l David baby doll: "this doll has true-to-life features which differentiate little girls from little boys. For those who feel they do not want their children to be aware of this difference, we do not recommend 
this doll" (Figure 9). The upper part of his package verbally stated that Li'l David baby had been America's best known and best loved doll since 1865 whereas the side part of his package did not bring much descriptive information except for appealing to this baby's sensory modality (KRESS \& VAN LEEUWEN, 2006) while stating that he was made out of washable material and that it had a soft skin that "you love to touch". The verbal message was followed by two processes, when it described that the baby "drinks" and "wets". This male white-skinned baby from 1970s used to come with a plastic pacifier, a baby bottle, a chatterbox, and a cloth diaper.

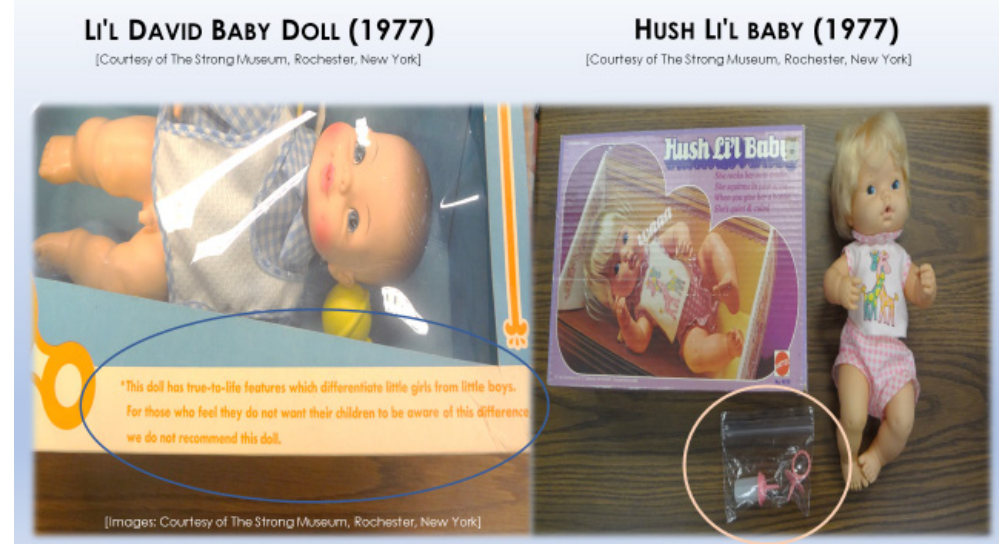

Figure 9. Li'l David Baby Doll and Hush Li'l Baby Courtesy of The Strong Museum, Rochester, New York

Indeed, in her comparative study on the packages of Baby Alive dolls and dolls from 1980's, using the GVD ${ }^{3}$ as one of her theoretical frameworks, Santos (2019) has pointed out to the anthropomorphic, thematic and figurative trajectory that guides baby dolls' representations: they drink, pee, eat, poo and play, and their activities are reinforced by the discourse of maternity made explicit in these dolls' packages. Their gendered messages are clear: responsibility in child-raising is generally attributed to the girl, as no male child is seen depicted in the analysed packages ${ }^{4}$.

Other studies have also focused on baby dolls' multimodal messages. Considering their modality level, Almeida (2018) has stated that baby dolls like

3. Grammar of Visual Design (GVD)

4. For other studies on baby dolls' texts, please refer to Almeida (2018). "It can cry, it can speak, it can pee": Modality Values and Playing Affordances in Contemporary Baby Dolls' Discourse. Ilha do Desterro. Florianópolis: Santa Catarina. 
Brazilian Coleção Nino's, Minba Dodoizinha Gessinbo, Analu Sorinbo's, Nina Baby and Betsy Doll all seem to embody what Varney (1999) has named tecbnocracy of sensuality (my italics): from a visual, tactile, aural and olfactory perspective, these dolls have been multimodally designed to appeal to every possible sense of its consumer.

Varney's (1999) concept of technocracy of sensuality applied to toys refers to the sensorial mechanisms which are added by the industry to make some toys more appealing at the sensorial level, which ends up lowering their play value or as Brougère (2014) names it, their playing affordances. Brougère (2014) defines playing affordances as the scripts or playing possibilities offered by toys' representations which are linked to the structures proposed by toys' design, shape and/or colours. Varney (1999) therefore expands on that by stating that in order to make toys more sensual and more eye catching, the industry may use colours, smell, flavours, light, sounds, by making them become more sensually appealing to the senses for marketing and/or sales purposes.

This marketing phenomenon of applying the so-called technocracy of sensuality to toys' design can be clearly seen in the baby dolls investigated in the Multimodality \& Childhood project: in terms of naturalistic modality, most of our analysed baby dolls cry out real tears, have bearts that beat like real ones, make sounds, pee and weigh like real babies, while others, when exposed to the sunlight get red cheeks. Such high modality ends up adding an anthropomorphic feature to these baby dolls' materiality by making them become more humanized. In other words, their modality - especially the degree of naturalistic and sensory modality of their representations - gets amplified both at the verbal and the visual level in these Brazilian contemporary baby dolls. The findings have been encapsulated in Figure 10.

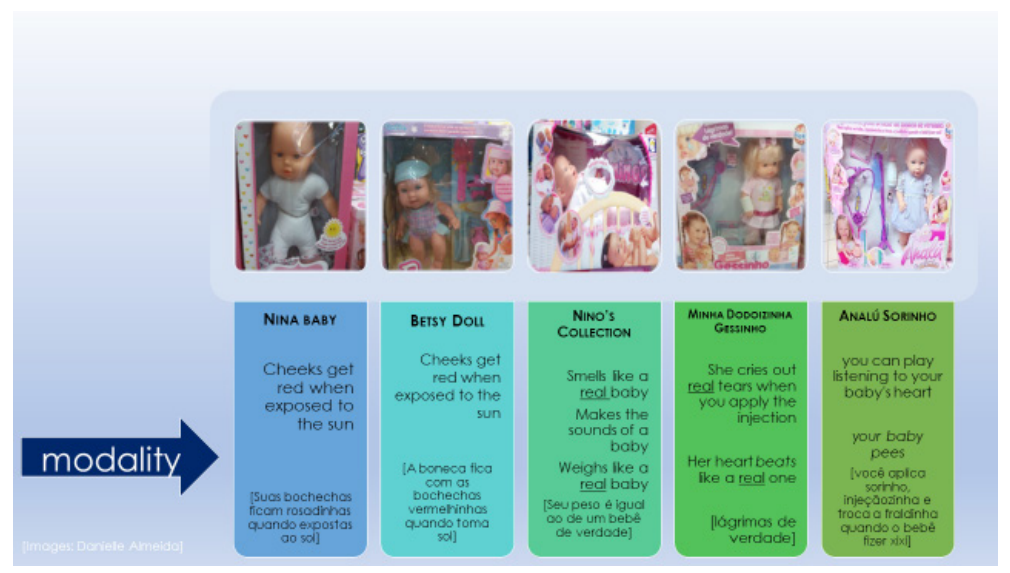

Figure 10. Realization of Modality in Brazilian Baby dolls [Source:author] 
If we relate an increasingly modality level in contemporary baby dolls to higher prescriptive playing scripts in toys of the kind, what we have just described as being tendencies in the baby dolls of mid 2010s leads us to infer that there seems to be a tendency towards prescription in contemporary toys' playing affordances. Next Figure rounds off what we have found out in terms of baby dolls' multimodal affordances through our careful observation of their verbal and visual patterns.

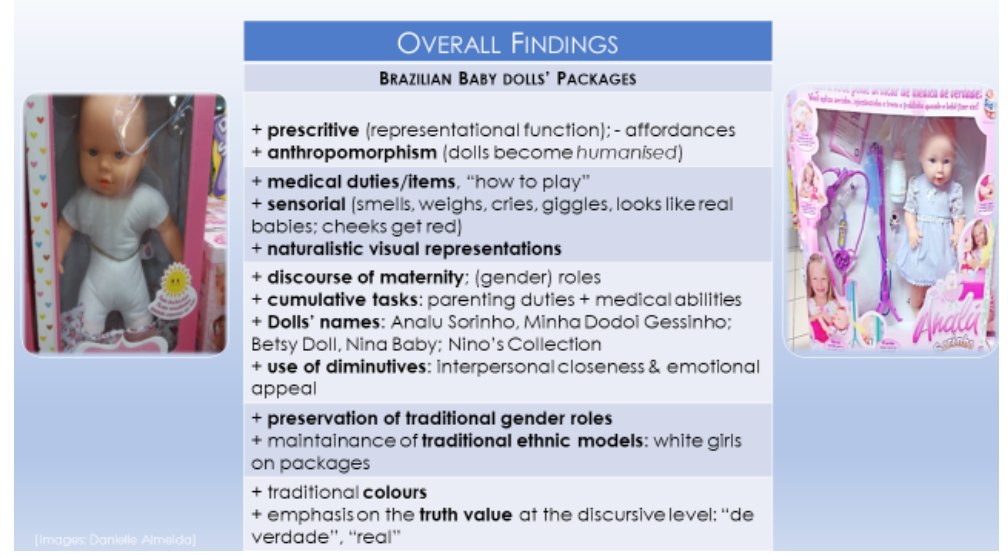

Figure 11. Overall findings of Brazilian baby dolls' analyses

[Source:author]

The relationship that connects toys' materiality to prescription will be further detailed in section 4 that follows.

\section{TOWARDS A MULTIMODAL FRAMEWORK TO TOY SEMIOTICS}

Toys' material dimension seems to be closely related to the idea of toys as texts. By observing toys' kinetic design at the tactile level and checking on aspects such as their texture, smell, kinetic possibilities and the degree of realism of their representations, it is possible to refine one's view about issues like toys' attached gendered meanings, as toys material configurations can reveal about their ideology.

Besides focusing on the verbal and visual syntactic patterns of their packages and advertisements, the description and analysis of toys' aural, olfactory and tactile aspects can be associated to the degree of modality of their representations. This can be done through the subsystem of modality within the interactive visual metafunction 
of the GVD, which has proved effective for the analysis toys' properties as three dimensional objects.

In terms of truth - or modality - value, two levels of signification have proved particularly effective in the investigation of toys' material properties: the sensory and the naturalistic modality. For Kress and van Leeuwen (2006), sensory coding orientation for modality uses colour as a source for pleasure and affective meanings, as colour can be regarded as a pleasure principle.

For authors such as Varney (1999), as it has been spelled out in the previous section, such pleasure principle derives from what she regards as technocracy of sensuality, a term used to refer to the sensorial mechanisms (sound, smell, weigh and light effects) which are added by the industry to make toys more appealing at the sensorial level, which ends up, she points, lowering their play value, i.e., their playing affordances. In other words, for Varney (ibid.) making toys more sensual has to do with making them more eye-catching through colours, smell, flavours, light, sound, i.e, more sensually appealing for marketing purposes. Varney therefore refers to certain toys as being gender demarcated, entwined in elaborated marketing programs, and also beavily sensualized (my italics).

As Varney's (1999) concept of technocracy of sensuality seems to relate to Kress \& van Leeuwen's (2006) sensory coding orientation for modality, Fleming's (1996) notions of barder representationality and tactile attachment seems to run parallel with the concept of naturalistic modality as both concepts account for the degree of realism in toys' representations and the interpersonal meanings generated by their material qualities.

For Fleming (1996), the notion of tactile attachment is related to the flexibility and sense of cuddliness of some toys, initiated with the Teddy Bear production in 1903. Harder representationality, on the other hand, is a concept that has to do with the bigh degree of realism of baby-like dolls.

As an attempt to relate these concepts visually, let us take a look at Figure 12: 


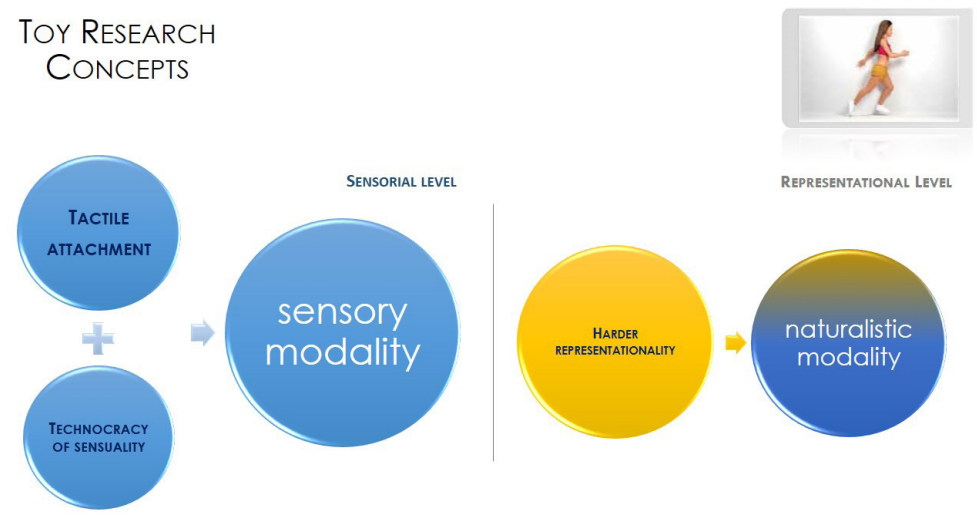

Figure 12. Combining and correlating concepts for the elaboration of a toy multimodal framework [Source:author]

But to what extent does a high degree of modality and sensuality in toys affect children's playing affordances?

For Benjamin (1984), the more imitative a toy becomes, the more it deviates from real life playing activity. An example would be toys designed to scent like flowers, fruits and babies, toys with lighting and sound effects maximized at their full spectrum. Peers (2001) also states that the more lifelike a baby doll is, the more prescriptive it becomes.

As sensory coding orientation for modality can vary from high to low, depending on how subjectively a representation affects its viewer $(+/$ - sensorial), that seems to relate to the affective reactions that certain toys and their materials appeal to our senses at the interpersonal level. Coding orientation for naturalistic modality, on the other hand, refers to how close to reality a given representation is (+/- naturalistic).

Taking the example of the Reborn line of baby dolls ${ }^{5}$ available at the market, when compared to most mainstream baby dolls found in toy stores, one can say that Reborn babies' level of naturalistic and sensory modality can be regarded as extremely bigh since they are designed to look, smell and weigh like real babies. So from a visual and kinetic perspective, the degree of their modality is maximized [+ barder representationality; + tactile attachment ${ }_{i}+$ sensual $]$. That also happens from a tactile and olfactory point of view. That seems to be the case not only of baby dolls, but costume and fashion dolls, war toys, replica animals and cars, all of which tend to

5. Available at https://www.reborns.com/ 
have a barder representationality in Fleming's terms - or bigher naturalistic modality when compared to other kinds of toys, therefore being considered $[+$ representational + naturalistic] in terms of degree of realism but [+ prescriptive] in terms of playing affordances and sometimes [- sensorial/sensual] in terms of evoking affective reactions.

Other toys like soft and plush toys, rag dolls and teddy bears tend to call for tactile attachment by evoking feelings of reassurance, intimacy and security through their material qualities. On the other hand, they tend to be considered [- representational in terms of barder representationality; - naturalistic in terms of modality and - prescriptive but generally $[+$ sensorial + sensual $]$ in terms of technocracy of sensuality, when it comes to evoking what Kress and van Leeuwen (2006) regard as the "pleasure principle" and its attached affective meanings.

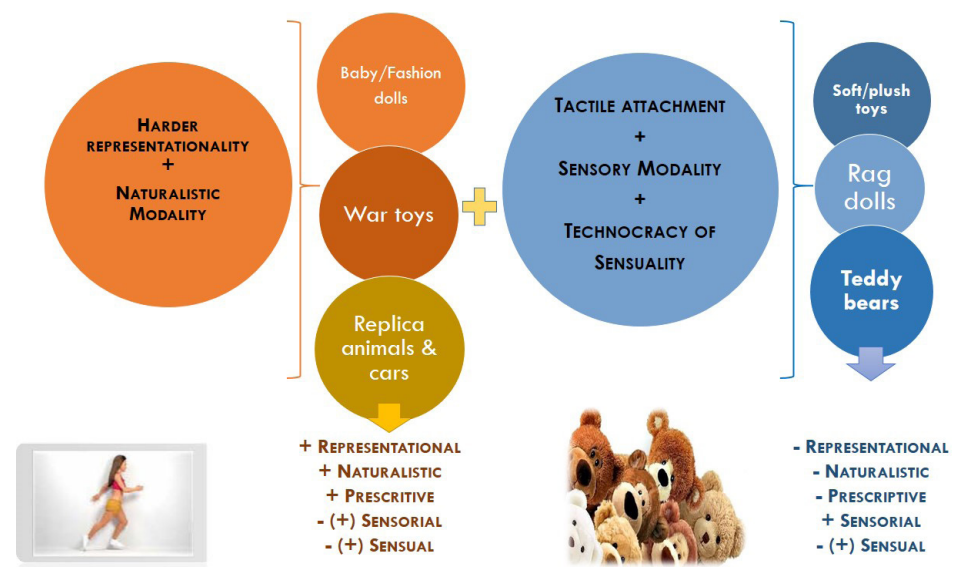

Figure 13. Key concepts for toys' multimodal analysis

[Source:author]

Important, though, is to remember that coding orientation for modality does not hold a one-to-one relation in terms of verisimilitude. In their multimodal analysis of war toys, Machin and van Leeuwen (2009) concluded that although the naturalistic modality [or harder representationality] of such kind of toys is generally regarded as very high - taking that some toy guns might look like real replicas of actual guns - on the tactile and aural level, these toys' modality level is actually very low, as they may be surprisingly light in terms of weight, therefore being far from the real thing and somehow amusing in terms of their sound effects. In that case, the bigh sensory modality in these toys ends up decreasing the naturalistic level of their modality. 
By relating these five concepts - namely, sensory and naturalistic modality, technocracy of sensuality, barder representationality and tactile attachment - to the analysis of toys' materiality, we can infer that tactile attachment and technocracy of sensuality seem to hold an equivalent correspondence to Kress \& van Leeuwen's (2006) concept of sensory modality just as the notion of barder representationality seems to bear a resemblance to the concept of naturalistic modality. Whereas the latter account for the degree of realism in toys' representations, the former refer to the interpersonal meanings generated by their material qualities.

Next Figure summarises our proposal for a framework to the analyses of toys' multimodal configurations and their attached potential meanings:
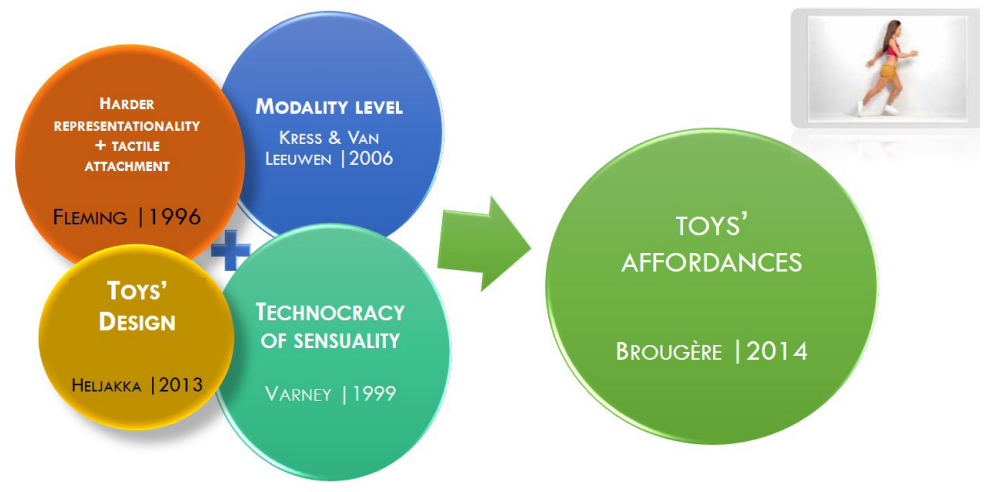

Figure 14. Framework for toys' multimodal analysis

[Source:author]

The framework can also be enhanced by adding Heljakka's concepts (2013) to describe what she calls the 'indefinable' qualities of a toy experience, essential to create a sense of 'wow-ness' in the player, since focus should not only be given to toys' visual and sensory aspects but also to their affectionate, narrative, sustainable and anthropomorphistic values.

The combination of these multimodal elements seems to have a huge impact on the flow of the playing activity and on toys' potential for playing affordances.

\section{CONCLUDING REMARKS}

The present article has gone through the context, research questions and theoretical pathways that have guided seminal toy projects in Brazil and in Britain 
in the late 1990s and early 2000s. It has also attempted at demonstrating how toys' analyses in the Brazilian projects have reacted to the application of the system of meanings of the Grammar of Visual Design such as the coding orientation for modality to address aspects such as the interpersonal meanings generated by the sensorial experience evoked by toys' material properties. When combined with concepts such as Varney's (1999) technocracy of sensuality and Fleming's (1996) notions of barder representationality and tactile attachment, the framework proposed for analysing toys' multimodality has proved particularly effective.

Last but not least, it should be said that other systems could likewise be assessed to investigate toys' multimodal messages, such as the representational metafunction, taken that it can be used to identify aspects such as the prescriptive instructions in toys' packages' through the identification of recurrent visual patterns in order to see how toys' given meanings interfere with children's own playing affordances.

It seems that there are still many other levels of signification in toys' discourse to be unveiled, as the pathway to the elaboration, application and discovery of a framework for toys' linguistic analysis is just at its beginning.

\section{REFERENCES}

ALMEIDA, D. B. L. (2018). "It can cry, it can speak, it can pee": Modality Values and Playing Affordances in Contemporary Baby Dolls' Discourse. Ilba do Desterro. Florianópolis: Santa Catarina.

ALMEIDA, D. B. L. (2017). On Diversity, Representation and Inclusion: New Perspectives on Toys' Discourse. Revista Linguag(em) Discurso. Universidade do Sul de Santa Catarina. Catarina, Santa Catarina, ISSN 1982-4017, p. 257-270, v.17, número 2, maio-agosto.

ALMEIDA, D. B. L. (2017).; ITRA NEWSLETTER International Toy Research Association Vol. 21 No. 2 Winter 2017. International Toy Research Association Newsletter: Winter Issue, United Kingdom, p. 11-11, 26 dez. 2017.

ALMEIDA, D. B. L. (2014). The political values embedded in a child s toy: The case of Girl Power in the Brazilian doll Susi. In: Visual Communication. Series: Handbooks of Communication Science [HoCS]. Machin, D. (Ed.).1ed.: De Gruyter Mouton, v. 1, p. 539-564.

ALMEIDA, D. B. L. (2011). Revisiting children's studies through the lens of the sociology of childhood. Poiésis (Tubarão), v. 4, p. 473-484. 
ALMEIDA, D. B. L. (2009). Where have all the children gone? A visual semiotic account of advertisements for fashion dolls. Visual Communication (Print), v. 8, p. 481-501.

ALMEIDA, D. B. L. (2008). Beyond the Playground: The Representation of Reality in Fashion Dolls' Advertisements. Linguag(em) (Dis)curso (Impresso), v. 8, p. 203-228.

ALMEIDA, D. B. L. (2006). Icons of Contemporary Childhood: A Visual and Lexicogrammatical Investigation of Toy Advertisements. 215 f. Tese de Doutorado. Florianópolis: Universidade Federal de Santa Catarina.

ALMEIDA, D. B. L. (2006). Sobre Brinquedos e Infância: Aspectos da Experiência e da Cultura do Brincar. Educação \& Sociedade (Impresso), v. 27, p. p.541-551.

ALMEIDA, D. B. L. (2006). Construções Ideológicas do Discurso Midiático: O Caso dos Anúncios de Brinquedos. Letra Viva (UFPB), v. 7, p. 9-21.

BROUGÈRE, G. (2014) Toys or the Rhetoric of Children's Goods. In: Machin, D. (ed.). Visual Communication. Series: Handbooks of Communication Science [HoCS] Vol. 4. Berlin: DeGruyter Mouton.

BROUGÈRE, G. (2004) Brinquedos e companbia. Trad. Maria Alice A. S. Dória. Rev. Gisela Wajskop. São Paulo: Cortez.

BROUGÈRE, G.(2003) A Study of the Make-Up of Children's Toy Collections. Toy Research in the Late Twentieth Century. SITREC - KTH. Stockholm International Research Centre. pp. 107-118.

CALDAS-COULTHARD, C. R. \& VAN LEEUWEN, T. (2004). Discurso Crítico e Gênero no Mundo Infantil: Brinquedos e Representações de Atores Sociais. In: Revista Linguag(em) Discurso, volume 4, número especial.

CALDAS-COULTHARD, C. R. \& VAN LEEUWEN, T. (2002) Stunning, Shimmering, Iridescent: Toys as the Representation of Gendered Social Actors. In Litosseliti, Lia \& Sunderland, Jane (Eds.). Gender Identity and Discourse Analysis. Amsterdam: John Benjamins, pp. 91-108.

CALDAS-COULTHARD, C. R. \& LEEUWEN, VAN LEEUWEN, T. (2001). Baby’s First Toys and the Discursive Constructions of Babyhood. In: Folia Linguistica 35 (1-2). 2001.

FALKSTROM, M. (2003). Action Man doesn't have a wife. I haven't seen that on the telly anyway: 6-8-year-olds about their toys from a gender perspective. Toy Research in the 
Late Twentieth Century. SITREC - KTH. Stockholm International Research Centre. pp. 263-275.

FLEMING, D. (1996) Powerplay: Toys as Popular Culture. Manchester: Manchester University Press.

KRESS, G. \& VAN LEEUWEN, T. (2006) Reading Images: The Grammar of Visual Design. London: Routledge.

MACHIN, D.; VAN LEEUWEN, T (2009). Toy as discourse: children's war toys and the war on terror. Critical Discourse Studies, 6 (1), pp. 51 - 64. Routledge.

MAIA, A. A. M.; ALMEIDA, D. B. L.; FERREIRA, J. (2018) Princesas Disney em Ação: Relações de Gênero e Modos de Ler o Mundo no Ensino de Língua Inglesa. In: Cleber Ataíde. (Org.). Gelne 40 anos: Vivências Teóricas e Práticas nas Pesquisas em Linguística e Literatura. 1ed.: v. 2, p. 131-149.

MOREIRA JUNIOR, M.; ALMEIDA, D. B. L. (2018) Letrar Brincando: Cantigas de Roda como Textos Multimodais e Ferramentas Culturais no Contexto Escolar. In: Zaira Santos, Clarice Gualberto, Sônia Pimenta. (Org.). Multimodalidade e ensino: múltiplas perspectivas. 1ed. São Paulo: Editora Pimenta Cultural, v. 1.

PEERS, J. (2004) The Fashion Doll: from Bébé Jumeau to Barbie. Oxford: Berg.

SANTOS, J. B. (2019). Entrando na Brincadeira: Uma Análise Semiótica da Imagem de Criança em Embalagens de Bonecas. Dissertação de Mestrado. 73 f. João Pessoa: Universidade Federal da Paraíba.

SELANDER, S. Toys as Text (2003). Toy Research in the Late Twentieth Century. SITREC KTH. Stockholm International Research Centre. pp. 39- 46.

SOARES, J. L. S.; ALMEIDA, D. B. L. (2018). Brinquedos como Representação Social e de Gênero na Infância: A Resignificação do Conceito de Família. Discursos Contemporâneos em Estudo, v. v. 3 (2), p. 19.

VARNEY, W. (2003). Toys, Technology and Social Shaping. In: Berg-Lars-Erik; Nelson, Anders, Svensson, K. (eds). Toys in Educational and Socio-Cultural Contexts. SITREC KTH. Stockholm International Research Centre. pp. 181-189.

VARNEY, W. (2003). Tamagotchis: All Byte, No Bark. In: Berg-Lars-Erik; Nelson, Anders, Svensson, K. (eds). Toys in Educational and Socio-Cultural Contexts. SITREC - KTH. Stockholm International Research Centre. pp. 277-288. 
VARNEY, W. (1999). Toys, play and participation. In: Brian Martin (ed.), Technology and Public participation. Wollongong, Australia: Science and Technology Studies, University of Wollogong, pp. 15- 36.

Recebido: 7/11/2019

Aceito: $12 / 10 / 2020$

Publicado: 15/10/2020 